\title{
Trisomy 10p syndrome owing to maternal pericentric inversion
}

\author{
Ken-ichi Ohba, Shozo Ohdo, Tohru Sonoda
}

\begin{abstract}
A female infant with karyotype $46, X X, r e c(10)$,dup p inv(10)(p11.2q25.2)mat is presented. She had both duplication of $10 \mathrm{p}$ and deletion of distal $10 \mathrm{q}$, but only had the constellation of specific features characteristic of duplication of $10 \mathrm{p}$.
\end{abstract}

It is commonly thought that duplication of $10 \mathrm{p}$ results in a clinically recognisable chromosomal syndrome. Almost all such cases are inherited from translocation carriers. Only three cases of trisomy 10p syndrome owing to parental pericentric inversion have been reported. ${ }^{1-3}$ It has been noted that patients with deletion of distal 10q have no pathognomonic features.
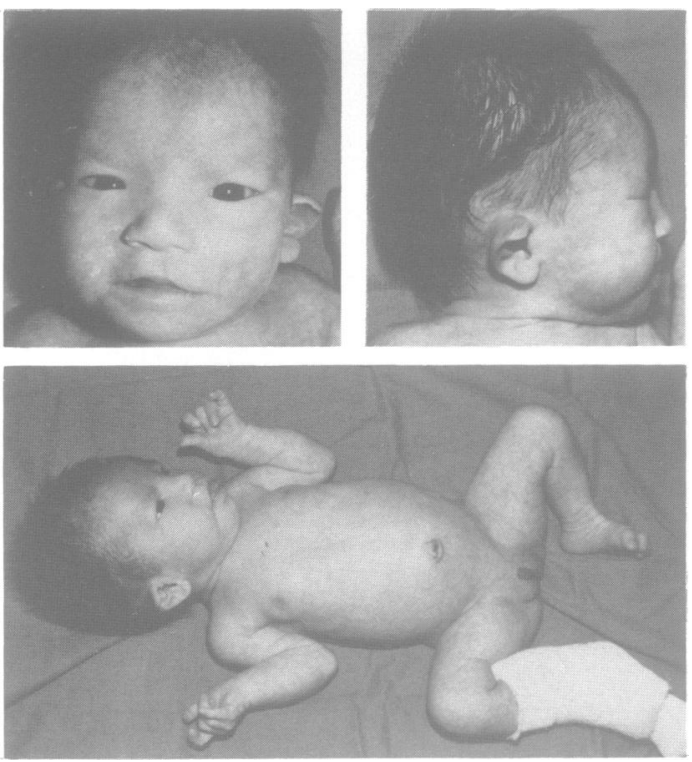

Figure 1 Clinical features of the proband at 2 months.

Department of Paediatrics, Miyazaki Medical College, 5200 Kihara, Kiyotake-cho, Miyazaki 889-16, Japan. K I Ohba, S Ohdo, T Sonoda

Correspondence to Dr Ohba.

Received for publication 8 July 1989.

Accepted for publication 14 July 1989

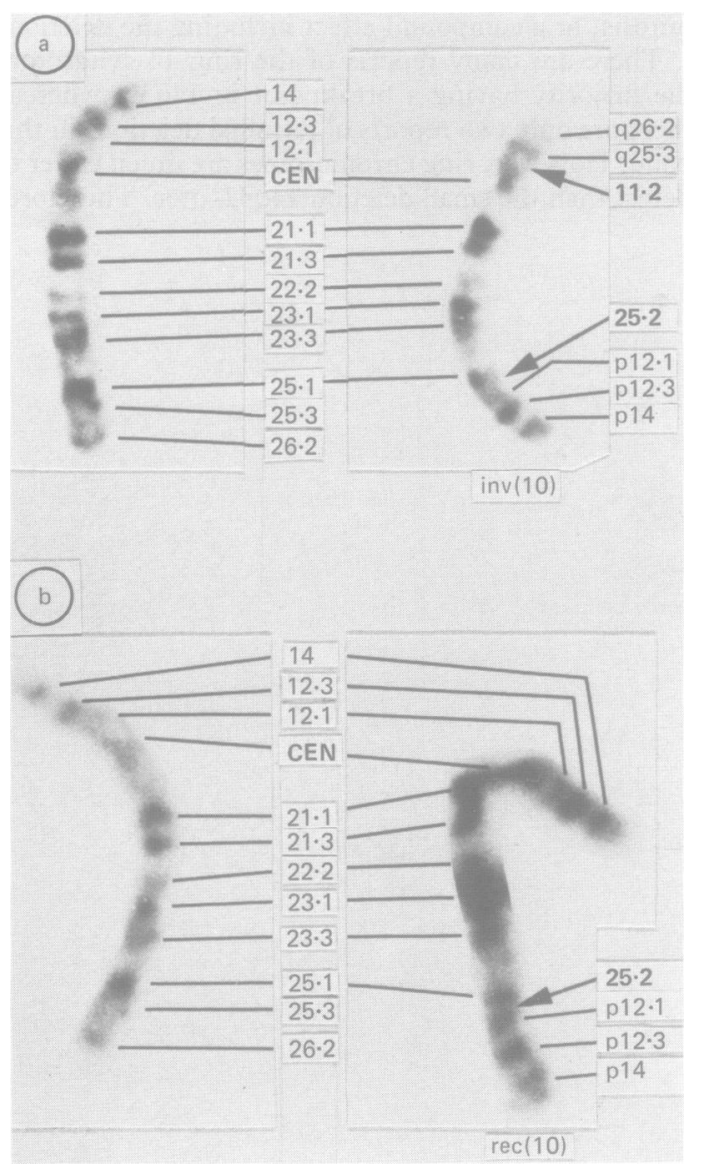

Figure 2 Partial karyotypes of chromosome 10 of mother and proband. (a) Partial karyotype of the mother,

46,XX,inv(10)(p11.2q25.6). (b) Recombinant chromosome of the proband. This recombinant chromosome represents both duplication of $10 p(p 11.2 \rightarrow$ pter $)$ and deletion of distal $10 q$ (q25.2 $\rightarrow$ qter).

\section{Case report}

The proband, a female, was born on 2.2 .88 at 41 weeks' gestation to healthy and unrelated parents; the father was 28 and the mother 29 years old. The mother's first conception resulted in spontaneous 
abortion, and the second in delivery of a healthy male infant.

The birth weight of the proband was $2322 \mathrm{~g}$. She was referred to our outpatient clinic aged 11 days because of peculiar facies and thrombocytopenia. At that time length was $47.5 \mathrm{~cm}(-2.0 \mathrm{SD})$, weight 2315 g $(-2 \cdot 2 \mathrm{SD})$, and head circumference $32 \mathrm{~cm}(-0 \cdot 7$ SD). Physical findings included a high, protruding forehead, a small face in relation to the cranium, large horizontal palpebral fissures, sparse eyebrows, broad and protruding nasal bridge, round and sagging cheeks, thin upper lips, turtle beak mouth, micrognathia, low set, malformed auricles, narrow thorax, hyperflexed upper limbs, clinodactyly of the fifth fingers, clenched hands, narrow pelvis, abducted hip joint, and club foot (fig 1). Dermatoglyphic analysis showed bilateral palmar transverse creases, 10 whorls, and high axial palmar triradii. There was no cardiac or renal malformation. Although the platelet count on the sixth day after birth was $2 \cdot 1 \times 10^{4} / \mathrm{mm}^{3}$, it rose to $24 \times 10^{4} / \mathrm{mm}^{3}$ on the 40 th day. Cultured blood lymphocytes showed a karyotype of $46, \mathrm{XX}, \operatorname{rec}(10)$, dup $\mathrm{p}, \operatorname{inv}(10)(\mathrm{p} 11.2 \mathrm{q} 25.2)$ owing to a pericentric inversion of a maternal chromosome 10 (fig 2). Both her maternal grandmother and maternal aunt had this pericentric inversion. Her father and brother had normal karyotypes.

At 12 months DQ was about 25.

\section{Discussion}

The present case had both duplication of $10 \mathrm{p}$ (p11.2 $\rightarrow$ pter) and deletion of distal $10 \mathrm{q}(\mathrm{q} 25.2 \rightarrow \mathrm{qter})$, but had specific features characteristic only of duplication of $10 \mathrm{p}$. The table shows the extent of recombinant chromosomes resulting from pericentric inversion of a parental chromosome 10 and the clinical features of previously reported patients with this karyotype. None of the cases reported by de la Chapelle $e t a l,{ }^{7}$ Husselein $e t a l,{ }^{8}$ and Simpson $e t a l^{9}$ with this pericentric inversion has had a liveborn infant with this recombinant chromosomal aberration. Patients reported by Rodriguez et $a l^{5}$ and Dutrillaux et $a t^{t}$ had clinical features characteristic of trisomy $10 \mathrm{p}$ syndrome (table). In a case with almost the same breakpoints in chromosome 10 as those of our case, none of the characteristic clinical features noted in trisomy $10 \mathrm{p}$ syndrome was found, and Yunis and de Caballero ${ }^{4}$ doubted the existence of a trisomy $10 \mathrm{p}$ syndrome. In view of the fact that a case studied by Nomoto et $a l^{2}$ with duplication of $10 \mathrm{pl} 3 \rightarrow$ pter had phenotypic features characteristic of the trisomy $10 p$ syndrome, it is not likely that the extent of duplication in the case of Yunis and de Cabellero was too small to cause characteristic features of the trisomy $10 p$ syndrome. Although the reason is still unclear, four cases $^{1-3}$ including our own had a constellation of features typically seen in the trisomy $10 p$ syndrome,

Clinical features in cases with recombinant chromosome owing to pericentric inversion of chromosome 10.

\begin{tabular}{|c|c|c|c|c|c|c|c|}
\hline & $\begin{array}{c}\text { Yunis and } \\
\text { de Caballero }\end{array}$ & $\begin{array}{l}\text { Lansky-Shafer } \\
\text { et } a l^{1}\end{array}$ & $\begin{array}{l}\text { Nomoto } \\
\text { et } a l^{2}\end{array}$ & $\begin{array}{l}\text { Sekhon } \\
e t a l^{3}\end{array}$ & $\begin{array}{c}\text { Rodriguez } \\
\text { et } a l^{5}\end{array}$ & $\begin{array}{c}\text { Dutrillaux } \\
e t a l^{6}\end{array}$ & $\begin{array}{l}\text { Present } \\
\text { case }\end{array}$ \\
\hline Extent of parental inversion & $\mathrm{pll} \rightarrow \mathrm{q} 25$ & $\mathrm{pll} \rightarrow \mathrm{q} 25$ & $\mathrm{p} 13 \rightarrow \mathrm{q} 26$ & $\begin{array}{c}\text { Not } \\
\text { described }\end{array}$ & $\mathrm{p} 15 \rightarrow \mathrm{q} 24$ & $\mathrm{p} 15 \rightarrow \mathrm{q} 24$ & $\mathrm{p} 11.2 \rightarrow \mathrm{q} 25.5$ \\
\hline
\end{tabular}

Findings in trisomy $10 p$

Dolichocephaly

High, protruding forehead

Large, horizontal palpebral fissures

Low set, large, malformed ears

Broad, protruding nasal bridge

Round, sagging cheeks

Turtle beak mouth

Hyperflexed upper limbs

Abducted, flexed lower limbs

Club foot

Hypotonia

Excess of whorls

Cardiac malformation

Renal malformation

Ocular abnormalities

Hypoplastic genitalia

Findings in trisomy $10 q$

Microcephaly

Round, wide, flat face

Narrow palpebral fissures

Microphthalmos

Hypoplastic nasal bridge

Ligamentary hyperlaxity

Clinodactyly

Phenotype

\begin{tabular}{|c|c|c|c|c|c|c|}
\hline- & + & + & : & + & : & - \\
\hline+ & + & + & : & + & - & + \\
\hline- & + & $*$ & $*$ & - & - & + \\
\hline- & + & + & + & - & : & + \\
\hline+ & + & + & $*$ & - & - & + \\
\hline- & $*$ & + & $*$ & $*$ & $*$ & + \\
\hline- & + & + & $\because$ & * & : & + \\
\hline$*$ & + & : & 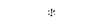 & * & 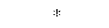 & + \\
\hline$*$ & + & + & $*$ & $*$ & 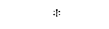 & + \\
\hline$*$ & + & - & + & $*$ & : & + \\
\hline * & + & + & $*$ & 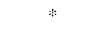 & + & + \\
\hline- & $*$ & $*$ & : & : & $*$ & + \\
\hline$*$ & $*$ & - & + & - & - & - \\
\hline+ & - & - & + & $*$ & $*$ & - \\
\hline$*$ & $*$ & * & $\Rightarrow$ & + & + & + \\
\hline * & + & + & + & $:$ & $*$ & - \\
\hline+ & * & $*$ & + & - & - & - \\
\hline$*$ & - & - & $*$ & * & + & - \\
\hline+ & - & - & $*$ & + & + & - \\
\hline$*$ & $*$ & $*$ & * & + & + & - \\
\hline * & - & - & + & + & + & - \\
\hline * & $*$ & * & $*$ & $*$ & $*$ & - \\
\hline * & - & * & * & + & + & + \\
\hline NC & $\begin{array}{c}\text { Trisomy } \\
10 p\end{array}$ & $\begin{array}{c}\text { Trisomy } \\
10 p\end{array}$ & $\begin{array}{c}\text { Trisomy } \\
10 p\end{array}$ & $\begin{array}{c}\text { Trisomy } \\
10 \mathrm{q}\end{array}$ & $\begin{array}{c}\text { Trisomy } \\
10 \mathrm{q}\end{array}$ & $\begin{array}{c}\text { Trisomy } \\
10 p\end{array}$ \\
\hline
\end{tabular}

* = not described or unclear.

$\mathrm{NC}=$ no characteristic features of trisomy $10 \mathrm{p}$. 
so it can be assumed that this syndrome might be found in many cases with this karyotype.

1 Lansky-Shafer SC, Daniel WL, Rutz L. Trisomy 10p produced by recombination involving maternal inversion inv(10)(p1 lq26). f Med Genet 1981;18:59-61.

2 Nomoto $N$, Nagauchi O. A partial 10p trisomy: 46,rec(10),dup p,inv(10)(p13q26)pat. Fpn f Hum Genet 1979;24:165A.

3 Sekhon GS, Sly WS. Trisomy 10p due to familial pericentric inversion. Birth Defects 1978;XIV (6C):422-3.

4 Yunis E, de Caballero OT. Duplication deficiency as the result of meiotic segregation of a maternal inv(10). Hum Genet 1981;57: $71-4$.
5 Rodriguez MT, Martin MJ, Abrisqueta JA. Familial pericentric inversion(10) and its effect on two offspring. 7 Med Gene 1984;21:317-9.

6 Dutrillaux B, Laurent C, Robert JM, Lejeune J. Inversion pericentrique, inv(10), chez la mere et aneusomie de recombinaison, inv(10), rec(10), chez son fils. Cytogenet Cell Genet 1973;12:245-53.

7 de la Chapelle A, Schroder I, Stenstrand K, et al. Pericentric inversions of human chromosome 9 and 10. Am f Hum Genet 1974;26:746-66.

8 Husselein P, Huber J, Wagenbichler P, Schnedl W. Chromosome abnormalities in 150 couples with multiple spontaneous abortions. Fertil Steril 1982;37:379-83.

9 Simpson JL, Elias S, Martin AO. Parental chromosomal rearrangements associated with repetitive spontaneous abortions. Fertil Steril 1981;36:584-90. 